\title{
Application of Sustainable Construction Materials for Urban Slum Houses
}

\author{
R. V. Ralegaonkar, H. R. Gavali, V. V. Sakhare, A. Puppala, and P. B. Aswath
}

\begin{abstract}
Meeting the demand for urban slum housing is one of the major challenges in front of government especially in developing countries like India. Traditionally, temporary and semi-permanent houses are being rebuilt by the government using commercially available products. The present paper briefs the application of sustainable construction materials to improve the energy efficiency of the permanent houses being built in Urban Slums. The concept is briefed with a case study over Nagpur, Maharashtra, India. Using locally available bio-fuel ash, cellular light weight (BFA-CLW) bricks were developed and recommended for the use as the masonry product. However, the traditional concrete roof is recommended to be treated with geofoam to improve thermal resistance. The proposed use of the materials (M1- BFA-CLW \& roof treated with geofoam) is compared with the traditional practice of design (M2- Fly ash brick with concrete roof). The cooling demand over the year for the considered geographic location was analyzed in the simulation software using building information modeling principals. The study resulted that the model M1 is energy efficient, cost competitive and shall conserve $46 \%$ of operating energy annually (cooling demand) as compared with conventional model M2. The study concludes with a note that the proposed model is a viable and practical acceptable solution.
\end{abstract}

Index Terms-Sustainable construction materials, energy efficiency, BFA-CLW, geofoam.

\section{INTRODUCTION}

Urbanization helps economic development of the nation. But, there is also a pressure of population growth and the escalation of slums. For example, with the estimated slum population of India (65 million), the technical committee estimated a minimum of 30 million additional houses to be built by 2020 [1]. In order to meet the ever increasing demand for construction materials, it is apt to use, low cost, locally available and low embodied energy materials as a sustainable solution that is helpful for reducing environmental impacts [2] In order to evaluate the performance of building design alternatives it is suitable to access the performance of the

Manuscript received August 21, 2016; revised October 20, 2016. This work was supported in part by the Indo-US Science and Technology Forum, Department of Science and Technology, India.

R. V. Ralegaonkar was with the Department of Civil Engineering at VNIT, Nagpur, India. He is currently with Material Science and Engineering Department, UTA, Texas, Arlington, US (e-mail: sanvan28@yahoo.com).

H. R. Gavali is with the Department of Civil Engineering at VNIT, Nagpur, India (e-mail: gavali.hr@gmail.com).

V. V. Sakhare is with the Department of Civil Engineering, BITS, Pilani, India (e-mail: vishakha.sakhare@gmail.com).

A. Puppala is with the Department of Civil Engineering, UTA, Texas, US (e-mail: anand@uta.edu).

P. B. Aswath is with Material Science and Engineering Department, UTA, Texas, Arlington, US (e-mail: aswath@exchange.uta.edu). system that has potential to conserve resources [3].

The selection of materials for building construction should satisfy the felt needs of the user as well as the development needs of the society, without causing any adverse impact on environment [4]. Several attempts were made for the utilization of waste in the development of masonry products which are light in weight and having low thermal conductivity. Reference [5] compared the strength and thermal insulation property of three types of blocks produced from waste materials: vermiculite, polystyrene beads and cement kiln dust, which were used as a partial replacement for cement. Results showed that lightweight concrete blocks manufactured from polystyrene had a lower thermal conductivity than vermiculite and ordinary concrete blocks. Reference [6] investigated the feasibility of application of recycled paper mill waste (RPMW), sugarcane bagasse ash (SBA), and construction-demolition waste (C\&DW) materials in the development of building masonry products and compared to commercially available products. The study resulted that the temperature of the model built with RPMW, SBA bricks and C\&DW bricks was $28 \%, 21 \%$ and $15 \%$ cooler than the fly ash brick model respectively. The embodied energy in basic building materials, different types of masonry materials, mortars, masonry and floor/ roofing systems and the energy expenditure in transportation of building materials was discussed in Indian context [4]. It was estimated, that the embodied energy (EBE) is lowest (2.092 $\mathrm{GJ} / \mathrm{m}^{2}$ ) for two storied houses, constructed with hollow cement-concrete block based masonry and the cost of building materials is found to be lowest (US\$ $62 / \mathrm{m}^{2}$ ) for four storied houses constructed with AAC block based masonry [7].

The appropriate design of thermal barrier over the roof surfaces plays a significant role to increase the thermal comfort inside the buildings. Reference [8] made focus on the formulation of polyester-clay composite as an insulating material that gives the best in terms of thermal and mechanical properties. Reference [9] investigated the thermal effects of newly designed passive cooling systems on concrete roofs in existing buildings. The rooftop lawn is seen to have many merits such as; reduction in the air conditioning load of buildings and contribute to the mitigation of the heat island phenomenon. In earlier research on the rooftop spraying system, Reference [10] presented a field study on a rooftop spraying system. The effect of roof spraying contributed to room temperature reduction in the summer season. Regarding the rooftop lawn, Reference [11] presented an experimental study on thermal characteristics and water performance of rooftop lawn. On the other hand, reference [12] clarified the indoor thermal control effect of rooftop lawn planting with 
thin soil layer on a wooden building.

Building Information Modeling (BIM) is an important IT application prevalent these days in the construction industry. The architecture, engineering, and construction (AEC) industry have long sought techniques to decrease project cost, increase productivity and quality, and reduce project delivery time. BIM offers the potential to achieve these objectives [13] Reference [14] demonstrated the contribution of BIM to sustainable building design from the two perspectives of integrated project delivery and design optimization. These are the two major beneficial features of BIM in relation to sustainable building design.

In view of above, the detailed study regarding current practices was carried out and elaborated in the manuscript further. Newer masonry product (Cellular light weight concrete block) using locally available raw material (bio-briquette ash) and having a better thermal resistance is considered. As the primary source of heat inside the building is from conventional roof retrofitting the traditional practice with available geofoam is considered for the treatment. The BIM modeling and detailed analysis are carried out to evaluate the reduction in cooling load. Finally, the embodied energy estimation and cost economics of the proposed model is carried out and was compared to the traditional practice to analyze the feasibility of the desired construction materials.

\section{CONSTRUCTION MODELING - MATERIALS AND METHODS}

\section{A. Housing Model}

As per the reference [15] in India the slum houses are being designed for an individual family of size 25-30 sq. m. A sample approved plan (Fig. 1) having a total built area of 27 sq. m. by the competent authority (Nagpur Municipal Authority) over the study area, Nagpur (Latitude: $21^{\circ} 9^{\prime} 0^{\prime \prime} \mathrm{N}$, Longitude: $79^{\circ} 6^{\prime} 0^{\prime \prime} \mathrm{E}$ ) is indicated as a Revit model.

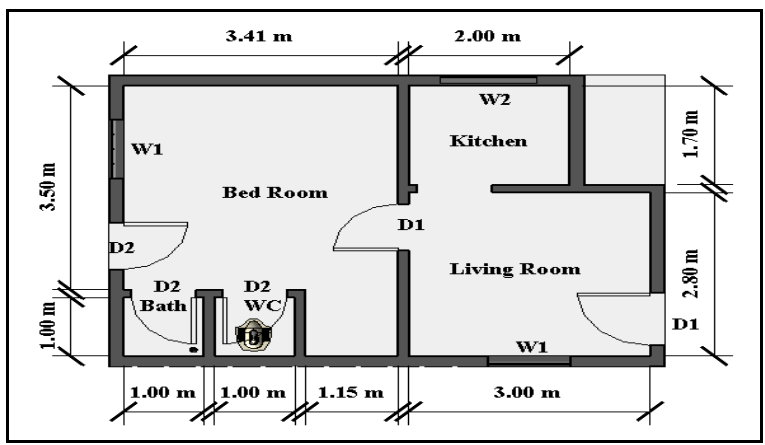

Fig. 1. Plan of considered slum house.

The considered model building is oriented towards North. The model consists of five rooms namely, living room (LR), bedroom (BR), kitchen (Kit), Bath and W/C. Height of the building is considered as $3 \mathrm{~m}$. The wall thickness is $150 \mathrm{~mm}$ (external) and $100 \mathrm{~mm}$ (internal). The provided size of the windows, $\mathrm{W} 1$ and $\mathrm{W} 2$ are $1 \mathrm{~m} \times 1.2 \mathrm{~m}, 1 \mathrm{~m} \times 0.52 \mathrm{~m}$ respectively. Size of doors, D1 and D2 are $0.9 \mathrm{~m} \times 2.1 \mathrm{~m}$ and $0.8 \mathrm{~m} \times 2.1 \mathrm{~m}$ respectively. Between LR and Kit opening $(\mathrm{O})$ in the wall of size $0.8 \mathrm{~m} \times 2.1 \mathrm{~m}$ is provided.

\section{B. Walling Material}

Commercially available sustainable product, i.e. fly ash bricks are commonly adopted for wall construction. However, newly designed and developed product Cellular lightweight blocks are recommended for further use [16]. The constituent materials used for BFA-CLW brick development are 53 grade ordinary Portland cement [17], bio-briquette ash samples collected from the locally available industry (Shree Baidyanath Ayurved Bhawan Pvt. Ltd., Nagpur) and foaming agent as per requirements of IS 9103: 1999. The dry ingredients, cement and ash are thoroughly mixed in a mechanical mixer with 1:3 proportions. Then around $60-70 \mathrm{~L}$ of water is added to $150 \mathrm{~kg}$ of cement and mixing is continued. The commercially available foaming agent made up of hydrolyzed protein base with foam stabilizers, metal salts, highly surface-active flurotensides and compensating agents is used. The foaming agent $(0.7 \mathrm{~L})$, water $(30 \mathrm{~L})$ and compressed air is mixed in a foam generator. The foam is mixed at the density of $58 \mathrm{~kg} / \mathrm{m}^{3}$. The CLW bricks are cast with the desired wet density of $1200 \mathrm{~kg} / \mathrm{m}^{3}$. It is mixed to make a uniform consistency. The obtained mix is further checked for desired density and then poured into the mold. After 24 hours, bricks are taken out of the molds. All the brick samples were kept in for one day air drying followed by the intermediate curing. The details of the considered bricks are as mentioned in Table I and Table II indicates the details of considered super structure material traditionally used for the construction.

\begin{tabular}{c|c|c|c}
\multicolumn{2}{c}{ TABLE I: COMPARATIE STUDY OF FLY ASH BRICKS AND BFA-CLW BRICKS } \\
\hline $\begin{array}{c}\text { Brick Type } \\
\text { (Size in mm }^{\mathbf{3}} \text { ) }\end{array}$ & $\begin{array}{c}\text { BFA-CLW Bricks } \\
(300 \text { X 150X 100) }\end{array}$ & $\begin{array}{c}\text { Standard } \\
\text { requirements }\end{array}$ & $\begin{array}{c}\text { Fly ash Bricks } \\
(230 \text { X 100 X 80) }\end{array}$ \\
\hline $\begin{array}{c}\text { Compressive } \\
\text { Strength } \\
\text { (MPa) }\end{array}$ & 3.58 & 3.50 & 12.50 \\
\hline $\begin{array}{c}\text { Water Absorption } \\
\text { (\%) }\end{array}$ & 12 & 12.50 & 14.64 \\
\hline Drying Shrinkage & No Shrinkage & - & - \\
\hline $\begin{array}{c}\mathbf{C o s t}_{\mathbf{m}^{3}} \\
\text { (INR) }\end{array}$ & 2242 & - & 2975 \\
\hline Reference & {$[16]$} & {$[18]$} & {$[19]$} \\
\hline
\end{tabular}

TABLE II: PHYSICO-MECHANICAL PROPERTIES OF WALLING AND ROOFING

\begin{tabular}{c|r|c}
\hline Material & $\begin{array}{r}\text { Density } \\
\text { Kg/ } \mathbf{~ m}^{\mathbf{3}}\end{array}$ & $\begin{array}{c}\text { Thermal } \\
\text { Conductivity } \\
\text { W/(m-K) }\end{array}$ \\
\hline Fly Ash Bricks & 1800 & 1.05 \\
\hline BFA-CLW Bricks & 1000 & 0.35 \\
\hline Plaster & 1120 & 0.721 \\
\hline RCC Slab & 2500 & 1.58 \\
\hline
\end{tabular}

\section{Geofoam as a Roof Insulating Material}

Expanded polystyrene (EPS) geofoam is a lightweight material that has been used in engineering applications since at least the 1950s. Expanded Polystyrene, EPS, geofoam is a super-lightweight, closed cell, rigid, plastic foam. Expandable polystyrene is the raw material or resin used for the molding of expanded polystyrene, EPS, geofoam. Expandable polystyrene is a plastic/polymeric material with a chemical composition of C8H8 [20]. Polymers are long chain molecules in which one to three basic units, monomers, are repeatedly linked over and over in a process called 
polymerization. $\mathrm{P}$ olymerization of styrene monomer used to be followed by impregnation of the polymerized polystyrene beads with a blowing agent. The reaction occurs in a single reactor designed to control the temperature and pressure of the reaction. Styrene monomer and water is charged to the reaction kettle equipped with an agitator. Various chemicals are added to affect suspension of the monomer in water and to control the polymerized bead growth, molecular weight and other parameters necessary to produce the desired product. In the second phase of the process, the blowing agent is added under pressure and impregnates the soft polystyrene beads. The total batch cycle takes a little less than ten hours. When completed the entire batch is dumped to de-water the system. The beads are then dried. The beads are screened to obtain different bead sizes. They will be in different grades each has its own specification and use. Some grades that are for general block and shape molding operations [21] are fed to a vertical tank containing an agitator and a controlled steam input. The final material density is determined at this stage. Density adjustment is carried out by controlling the length of the time the beads remain in the expander and/or the pressure in the ex-pander. Second, the expanded beads, called prepuffs, are stored in the open air for a few hours as a drying stage. Third, the prepuffs are stored in large silos until transferred to the following step. During storage they are allowed to reach an ambient temperature. This process takes as long as three days or as short as a few hours. This process is called the stabilization process, as condensation of the blowing agent and the surrounding water vapor occurs. The prepuffs then are poured into a mold of various sizes, depending on the manufacturer. A $0.6 \mathrm{~m} \times 1.2 \mathrm{~m} \times 2.4 \mathrm{~m}$ is a common mold size. Steam is injected from the walls of the mold through longitudinal tiny slots where fusion takes place. Approximately $5 \%$ of recycled expanded polystyrene (re-grind) is shredded and mixed with the prepuffs. Additional expansion and fusion take place. The moulded block is then pushed out where it is ultimately taken to a storage place to dry. The commercially available geofoam is considered for further analysis as a roof insulator. The properties as available from the manufacturer are specified below in Table II. The Geofoam Research Centre (GRC) at Syracuse University is dedicated to the research of geofoam properties, development of innovative applications, dissemination of technical information and technology transfer through education. More specific standards for geofoam are now under development by a newly formed "Geofoam Task Group" within ASTM Committee D-35 [22].

\begin{tabular}{l|r|r|r|r|c}
\multicolumn{7}{c}{ TABLE III: PROPERTIES OF GEOFOAM INSULATOR [23] } \\
\hline Insulator & I1 & I2 & I3 & I4 & I5 \\
\hline Density, Kg/m $\mathbf{3}$ & 12 & 15 & 18 & 22 & 46 \\
\hline Thickness, mm & 25 & 50 & 75 & 100 & 125 \\
\hline $\begin{array}{l}\text { Thermal Resistance, } \\
\left(\mathbf{m}^{2} . \mathbf{K}\right) / \mathbf{W}\end{array}$ & 0.55 & 0.63 & 0.67 & 0.70 & 0.76 \\
\hline $\mathbf{C o s t}, \mathbf{I N R} / \mathbf{~ m}^{\mathbf{3}}$ & 65 & 80 & 90 & 105 & 120 \\
\hline
\end{tabular}

\section{Revit Modeling}

The above range of insulating material (Table III) was coupled with conventional RCC slab (Table II) and energy simulation for annual cooling load demand estimation was carried out. SP 41 (1987) specified the comfort range of temperature as $18-27{ }^{\circ} \mathrm{C}$ over composite climatic zone (Representative City- Nagpur). The cooling load analysis was carried out for each room of the above model using following stepwise procedure (Fig. 2) in Revit Architecture.

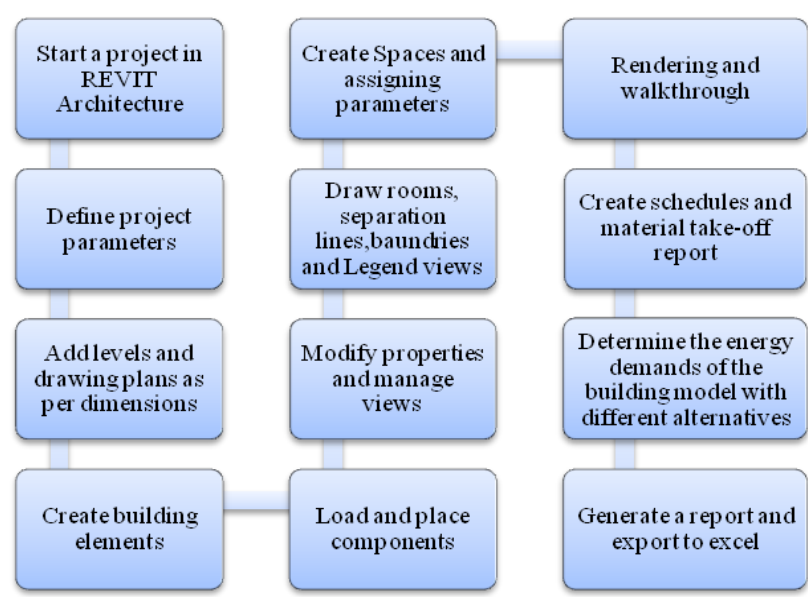

Fig. 2. Workflow of REVIT architecture modeling.

\section{RESULTS AND DISCUSSION}

The space created in the software once verified (Fig. 3) for desired material properties are further used to estimate the cooling load. For the base case, i.e. fly ash bricks with plastering on both internal-external sides and the RCC slab along with considered insulating material for roof analysis was carried out and the desired output is presented in Table IV.

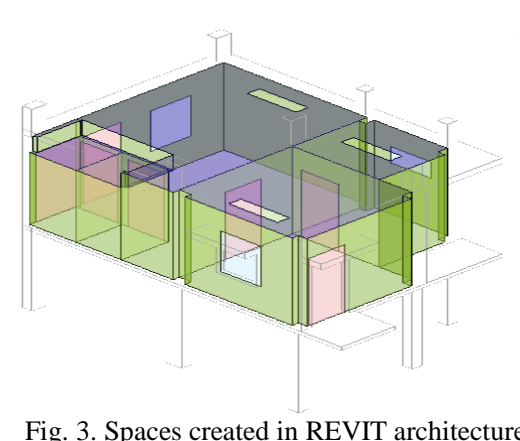

Fig. 3. Spaces created in REVIT architecture.

TABLE IV: COOLING LOAD ESTIMATION OF MODEL-FLY ASH BRICKS WITH

\begin{tabular}{|c|c|c|c|c|c|c|c|}
\hline \multicolumn{8}{|c|}{ VARIOUS RCC SLAB INSULATIONS } \\
\hline Case & $\begin{array}{l}\text { LR } \\
(W)\end{array}$ & $\begin{array}{l}\text { Bed } \\
(W)\end{array}$ & $\begin{array}{l}\text { Kitchen } \\
\text { (W) }\end{array}$ & $\begin{array}{l}\text { Bath } \\
\text { (W) }\end{array}$ & $\begin{array}{l}\text { WC } \\
(W)\end{array}$ & $\begin{array}{l}\text { Total } \\
\text { (W) }\end{array}$ & $\begin{array}{l}\text { Decrease } \\
\text { in Cooling } \\
\text { Load (\%) }\end{array}$ \\
\hline B0 & 1748.83 & 3022.45 & 1098.80 & 282.83 & 150.09 & 6302.99 & 0.00 \\
\hline B1 & 1490.85 & 2308.33 & 933.47 & 281.04 & 148.29 & 5161.98 & 18.10 \\
\hline B2 & 1479.76 & 2277.64 & 926.36 & 280.96 & 148.22 & 5112.94 & 18.88 \\
\hline B3 & 1474.93 & 2264.27 & 923.27 & 280.93 & 148.18 & 5091.59 & 19.22 \\
\hline B4 & 1471.58 & 2254.98 & 921.12 & 280.90 & 148.16 & 5076.74 & 19.46 \\
\hline B5 & 1465.45 & 2238.02 & 917.19 & 280.86 & 148.12 & 5049.63 & 19.89 \\
\hline B0 & \multicolumn{7}{|c|}{ Building with no insulating material } \\
\hline B1 & \multicolumn{7}{|c|}{ Building with insulating material of $\mathrm{R}$ value 0.55} \\
\hline $\mathrm{B} 2$ & \multicolumn{7}{|c|}{ Building with insulating material of $\mathrm{R}$ value 0.63} \\
\hline B3 & \multicolumn{7}{|c|}{ Building with insulating material of $\mathrm{R}$ value 0.67} \\
\hline B4 & \multicolumn{7}{|c|}{ Building with insulating material of $\mathrm{R}$ value 0.70} \\
\hline B5 & \multicolumn{7}{|c|}{ Building with insulating material of $\mathrm{R}$ value 0.76} \\
\hline
\end{tabular}

As the appreciable reduction in cooling demand was 
observed for case B1 and with due the constraint of cost the same insulator was fixed for further analysis. The feasibility of application of insulating material I1 (Table III) was also analyzed over the south face of the living room and the west wall of the bed room and is mentioned in Table V. It is observed from the table that suitable only roof is insulated one can conserve $18 \%$ energy demand required for cooling. However, if cost is not a constraint for the use of material one can have a maximum of $25.63 \%$ conservation of energy with all desired exposed building surfaces protected. However, as the present case deals with low cost house project cost needs to be competitive. Hence, the alternate suggested bricks (BFA-CLW) are further considered and the energy demand for cooling is analyzed further in the software.

TABLE V: COOLING LOAD ESTIMATION OF A MODEL-FLY ASH BRICKS WITH

\begin{tabular}{|c|c|c|c|c|c|c|c|}
\hline \multicolumn{8}{|c|}{ NALL AND RCC SLAB INSULATION } \\
\hline Case & $\begin{array}{l}\text { LR } \\
\text { (W) }\end{array}$ & $\begin{array}{l}\text { Bed } \\
(W)\end{array}$ & $\begin{array}{c}\text { Kitchen } \\
\text { (W) }\end{array}$ & $\begin{array}{c}\text { Bath } \\
\text { (W) }\end{array}$ & $\begin{array}{l}\text { WC } \\
(\mathbf{W})\end{array}$ & $\begin{array}{l}\text { Total } \\
\text { (W) }\end{array}$ & $\begin{array}{c}\text { Decrease } \\
\text { in } \\
\text { Cooling } \\
\text { Load }(\%)\end{array}$ \\
\hline B0 & 1748.83 & 3022.45 & 1098.80 & 282.83 & 150.09 & 6302.99 & 0.00 \\
\hline B1 & 1490.85 & 2308.33 & 933.47 & 281.04 & 148.29 & 5161.98 & 18.10 \\
\hline B6 & 1317.32 & 2308.33 & 933.47 & 281.04 & 148.29 & 4988.45 & 20.86 \\
\hline B7 & 1490.85 & 2007.42 & 933.47 & 281.04 & 148.29 & 4861.07 & 22.88 \\
\hline B8 & 1317.32 & 2007.42 & 933.47 & 281.04 & 148.29 & 4687.53 & 25.63 \\
\hline B & 1025.02 & 1553.03 & 601.83 & 153.67 & 82.33 & 3415.89 & 45.81 \\
\hline
\end{tabular}

B0 Building with no insulating material

B1 Building with insulating material of $\mathrm{R}$ value 0.55 (Treatment over RCC slab)

B6 Building with insulating material of $\mathrm{R}$ value 0.55 (Treatment over RCC slab and South wall of living room)

B7 Building with insulating material of $\mathrm{R}$ value 0.55 (Treatment over RCC slab and west wall of bed room)

B8 Building with insulating material of $\mathrm{R}$ value 0.55 (Treatment over RCC slab along with South wall of living room and west wall of bed room)

B* BFA-CLW Bricks \& RCC slab Treated with I-1

With reference to conventional practice, i.e. fly ash bricks and RCC roof slab, it is estimated that if BFA-CLW bricks along with RCC roof slab treated with insulator I1 (Table III), $45.81 \%$ of the energy required for cooling can be conserved. With the available commercial rate (Rs. $65 / \mathrm{m}^{3}$ ) and including the cost of carting and installation cost of insulator (material cost X 2.5) for the desired area of roof $\left(27 \mathrm{~m}^{2}\right)$ shall be Rs. 7350/-. Total cost of brick work for fly ash and BFA-CLW masonry was estimated at Rs. 57120/- and Rs. 47600/respectively. In all of the possible alternatives, i.e. BFA-CLW masonry with RCC slab insulation with I-1 shall be Rs. 54950/-which works out to be cost competitive (Rs. 2170 less than current practice). The embodied energy of considered bricks, i.e. fly ash and BFA-CLW is $52649 \mathrm{MJ}$ and $49890 \mathrm{MJ}$ respectively (V V Sakhare \& R V Ralegaonkar, 2016). For the desired roof insulator it is estimated as $1753.7 \mathrm{MJ}$ (Integrated Green Design- Central Public Works Design Guidelines). Thus, the total embodied energy of the considered alternative materials is 1005.3 MJ less as compared to present practice of the use of fly ash bricks.

\section{CONCLUSION}

The present study demonstrated the appropriate use of sustainable construction materials with the help of a case study. It is concluded in the specific case that the use of BFA-CLW bricks is more appropriate as compared to FA bricks as a walling material. For the considered case, insulating the roof was a more suitable option rather than protecting vertical walls. The obtained results indicated that the proposed solution for walling roofing application is cost competitive and an energy efficient model than the present state of the art practice of constructing urban slum houses. The suggested solution can practically be applied as a feasible and energy efficient solution.

\section{ACKNOWLEDGEMENT}

The first author gratefully acknowledges the support of Indo-US Science \& Technology Forum, Department of Science and Technology for kind financial support to undertake this study. Author is also thankful to the University of Texas, Arlington, USA and Visvesvarya National Institute of Technology, Nagpur, India for kindly extending desired facilities to carry out the work.

\section{REFERENCES}

[1] (March 2016). Housing for All (Urban) Scheme Guidelines. Pradhan Mantri Awas Yojana, Ministry of Housing \& Urban Poverty Alleviation, Government of India. [Online]. Available: http://www.nhb.org.in/Urban_Housing/HFA_guidelines_March2016 -English.pdf

[2] UN-Habitat. (Feb. 2011). Scoping Paper Sustainable Building Practices for Low Cost Housing: Implications for Climate Change Mitigation and Adaptation in Developing Countries. [Online] Available:

http://mirror.unhabitat.org/downloads/docs/10785_1_594340.pdf

[3] P. E. Moakher, "Building information modeling (BIM) and sustainability - Using design technology in energy efficient modeling," IOSR Journal of Mechanical and Civil Engineering, vol. 1, no. 2, pp. 10-21, July-Aug. 2012

[4] B. V. Reddy and K. S. Jagadish, "Embodied energy of common and alternative building materials and technologies," Energy and Buildings, vol. 35, no. 2, pp. 129-137, Feb. 2003.

[5] K. S. Al-Jabri, A. W. Hago, R. Taha, A. S. Alnuaimi, and A. H. Al-Saidy, "Strength and insulating properties of building blocks made from waste materials," Journal of Materials in Civil Engineering, vol. 21, no. 5, pp.191-197, May 2009.

[6] R. V. Ralegaonkar, M. V. Madurwar, S. P. Raut, S. A. Mandavgane, and V. A. Dakwale, "Application of solid wastes in sustainable building masonry products: a techno-environmental study," presented at ICSCI 2014, ASCE India Section, Hitex, Hyderabad, Telangana, India, Oct. 17-18, 2014.

[7] D. Bansal, S. Singh, and R. L. Sawhney "Effect of construction materials on embodied energy and cost of buildings - A case study of residential houses in India up to $60 \mathrm{~m}^{2}$ of plinth area," Energy and Buildings, vol. 69, pp. 260-266, Feb. 2014.

[8] K. Al-Malah and B. Abu-Jdayil, "Clay-based heat insulator composites: thermal and water retention properties," Applied Clay Science, vol. 37, pp. 90-96, Jan. 2007.

[9] J. L. Alvarado, W. J. Terrell, and M. D. Johnson, "Passive cooling systems for cement-based roofs," Building and Environment, vol. 44, no. 9, pp. 1869-1875, Sept. 2009.

[10] T. Tanabe, R. Sayama, and H. Saito, "Measurement of the effect of a change in slate-roofing from single to double with water spraying on lowering the ceiling surface temperature," Summaries of Technical Papers of Annual Meeting of the Architectural Institute of Japan, pp. 507-508, 2000. 
[11] O. Ishihara, Q. Zhang, and K. Shimoyama "Experimental study on thermal characteristics and water performance of rooftop lawn," Journal of Architecture, Planning and Environmental Engineering, vol. 484, pp. 17-22, Jun. 1996.

[12] A. Hoyano, K. Shirai, N. Otsuka, and K. Iwamura, "Indoor thermal control effect of rooftop lawn-planting with thin soil layer on a wooden building," Journal of Architecture, Planning and Environmental Engineering, vol. 527, pp. 15-19, Jan. 2000.

[13] S. A. Nadeem, "Building information modeling: A new paradigm for visual interactive modeling and simulation for construction projects," in Proc. First International Conference on Construction in Developing Countries, pp. 435-446, Pakistan.

[14] Department of Civil Engineering, NED University of Engineering \& Technology, Karachi, 2008.

[15] K. Wong and Q. Fan, "Building information modelling for sustainable building design," Facilities, vol. 31, no. 3/4, pp. 138-157, Feb. 2013.

[16] National Building Code of India, Bureau of Indian Standard, New Delhi, India, SP 7, 2005.

[17] V. V. Sakhare and R. V. Ralegaonkar. (May 2016). Development and investigation of cellular light weight bio-briquette ash bricks. Clean Technologies and Environmental Policy. [Online]. Available: DOI : $10.1007 / \mathrm{s} 10098-016-1200-5$

[18] 53 Grade Ordinary Portland Cement, Bureau of Indian Standards, New Delhi, India, IS 12269-2013.

[19] Preformed Foam Cellular Concrete Blocks, Bureau of Indian Standard, New Delhi, India, IS 2185 Part 4- 2008.

[20] S. P. Raut, S. A. Mandavgane, and R. V. Ralegaonkar, "Thermal performance assessment of recycled paper mill waste-cement bricks using the small-scale model technique," Journal of Energy Engineering, vol. 140 no. 4, p. 04014001, Dec. 2014.

[21] A. Ravve, Principles of Polymer Chemistry, 2nd ed., New York: Kluwer/Academic/Plenum, 2000, pp. 292-294.

[22] Huntsman, "Huntsman expandable polystyrene Grade 54," Huntsman Corporation, Texas, USA, Technical Bulletin, No. 4-4.1, 1999.

[23] A. F. Elragi. Selected engineering properties and applications of EPS Geofoam. [Online]. Available: http://www.michiganfoam.com/docs/eps_geofoam_selected_engineer ing_properties.pdf

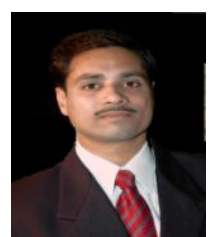

Rahul V Ralegaonkar working as associate professor in the Department of Civil Engineering, at Visvesvaraya National Institute of Technology, Nagpur, India. He is majorly working in the area of sustainable construction engineering. He has published more than 110 research papers in esteemed international and national journals and conferences. He contributed a chapter to premier reference source book "Smart Cities as a Solution for Reducing Urban Waste and Pollution" ed. Goh Bee Hua, IGI Global, Hershey, Pennsylvania (USA), June 2016, pp. 1-37. He completed several R \& D and consultancy projects in the broad area of energy efficient construction materials. He has guided 5 $\mathrm{PhDs}$ and more than 30 Master's students. He is a recipient of 2 fellowships, 3 state and 1 international awards. He is an active member of several National and International Professional bodies including CBEES.

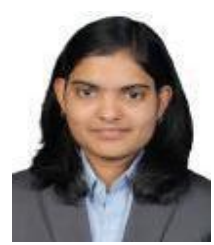

Hindavi R. Gavali has completed the B.Tech degree in civil engineering from Walchand College of Engineering, Maharashtra, India, in 2014 and the M. Tech degree in construction technology and management from Visvesvarya National Institute of Technology, Nagpur, India, in 2016. Presently she is a $\mathrm{Ph} . \mathrm{D}$. research Scholar at Visvesvarya National Institute of Technology, Nagpur, India. Her areas of research interest are Sustainable construction and Information modeling.

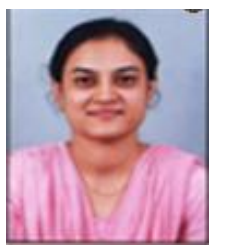

Vishakha V. Sakhare is currently assistant professor in the Department of Civil Engineering at Birla Institute of Technology (BITS), Pilani, India. She has completed her $\mathrm{PhD}$ in the sustainable construction materials from Visvesvaraya National Institute of Technology, Nagpur in the year 2016. She has more than 20 research papers in the international and national journal as well as conferences. Recently a chapter authored by her titled Sustainable Construction Materials is published by IGI global in the handbook on 'Smart Cities as a Solution for Reducing Urban Waste and Pollution'. She was awarded with International Innovation and Research Award by CIOB, UK for Masters Dissertation in the year 2012. She is a member of professional bodies like ASCE (Affiliate Member) and CBEES.

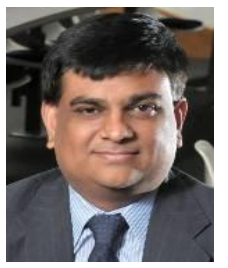

Anand Puppala is a professor of civil engineering and coordinator of the geotechnical engineering program at The University of Texas (UTA). He is the current chairman of the TRB committee on Soil and Rock Instrumentation (AFS 20). He served as chair of the American Society of Civil Engineers' (ASCE) Geotechnical Institute's Engineering Geology and Site Characterization Committee from 2003-2006. He also recently completed his term (2007-2009) as president of the United States Universities Council on Geotechnical Education and Research (USUCGER). He has authored or co-authored 6 book chapters and more than 150 publications in esteemed Journals and Conferences. He has supervised 11 doctoral and 30 master's students. He has received numerous awards. He currently serves as an editor for three prestigious journals, including the American Society of Testing Materials' Geotechnical Testing Journal and the American Society of Civil Engineers' journals of Materials, and Geotechnical and Geoenvironmental Engineering. He is also the deputy chief editor of Thomas Telford's Ground Improvement Journal (UK) and has edited several books, including ASCE's Geotechnical Special Publication on Site Characterization.



Pranesh B Aswath is a professor of the Department of Materials Science \& Engineering and holding the position of Vice Provost, Academic Planning and Policy at University of Texas at Arlington, USA. He has over twenty five years of experience in the area of processing of advanced materials that include monolithic and composite materials. In addition, he has over 20 years of experience in the area of deformation, fatigue and fracture of specialty engineering materials. His work in the area of synthesis of materials involves the design of new materials using fundamental concepts in chemistry, thermodynamics and material science. One of the initiatives which he is involved in research is the development of sustainable concrete An additional area of interest is in the development of concrete reinforced with bamboo. It is a collaborative effort with faculty in Civil engineering. With the active participation in international professional bodies, he is also involved with several industrial research and consultancy projects. He won three prestigious awards. Under his guidance around $15 \mathrm{PhDs}$ and 30 master's students completed the work. He has more than 20 research funded projects, 7 patents and around 140 research papers in esteemed Journal and conferences to his credit. 